\title{
FIRST AND SECOND TIER PROPERTIES OF HIP AND FORGED P/M 706
}

\author{
U. Habel, F.J. Rizzo, J.J. Conway \\ Crucible Materials Corporation \\ R. Pishko, V.M. Sample, G.W. Kuhlman \\ Aluminum Company of America
}

\begin{abstract}
Powder metallurgical (P/M) versions of Inconel ${ }^{\circledR} 706$, an iron/nickel-base superalloy, were evaluated*. The materials were gas atomized, consolidated by hot isostatic pressing (HIP) and subsequently forged to small pancakes. Effects of powder metallurgical processing parameters were investigated such as atomization gas, powder particle size fraction and HIP temperature. P/M 706 has a finer microstructure and a higher resistance to grain growth than conventionally cast and wrought $(\mathrm{C} / \mathrm{W}) 706$. High temperature hot compression testing shows about $10 \%$ lower flow stress for $\mathrm{P} / \mathrm{M} 706$ than for $\mathrm{C} / \mathrm{W} 706$. Tensile properties of as-HIP and solution treated and aged P/M 706 compare favorably to forged, solutionized and aged C/W 706, while Charpy impacl strenglh is lower. Due to overaging in this study, HIP, forged, solution treated and aged P/M 706 has a lower strength than usually observed in forged, solution treated and aged $\mathrm{C} / \mathrm{W} 706$. Low cycle fatigue results are excellent and exceed C/W 706 values by factors of 3 to 5 . The fine and homogeneous grain size and the absence of any significant segregation observed in the P/M 706 is expected to greatly facilitate forging of large turbine disk shapes.
\end{abstract}

* Inconel ${ }^{\circledR}$ is a registered trademark of the INCO family of companies.

\footnotetext{
Superalloys $718,625,706$ and Various Derivatives Edited by E.A. Loria

The Minerals, Metals \& Materials Society, 1997
} 


\section{Introduction}

Inconel $^{\circledR *}$ superalloy 706 , a precipitation hardenable nickel-iron-base alloy, is characterized by good mechanical properties at high temperatures combined with good corrosion resistance [1]. Other alloys of this type are Inconel ${ }^{\circledR} 901$, Inconel ${ }^{\circledR} 718$ and Alloy A-286 [2]. Alloy 706 is less prone to segregation than Alloy 718 due to the lower levels of niobium and aluminum and absence of molybdenum in the former. To achieve a sufficient strength level, more titanium is added in Alloy 706.

Alloy 706 is frequently used for very large forgings in applications such as gas turbine components and chemical processing [3], [4]. The most advanced cast and wrought $(\mathrm{C} / \mathrm{W})$ processing includes triple melting: Vacuum induction melting, electroslag remelting and vacuum arc remelting (VIM, ESR and VAR) [5]. This way of processing reduces, but may not totally avoid melt-related defects and segregation, especially in very large parts. Also, C/W 706 is prone to grain growth and therefore requires low forging temperalures which necessitates very large pressing forces [6].

Segregation can be avoided and melt-related defects can be significantly reduced by powder metallurgical (P/M) processing which results in very fine and homogeneous microstructures. This is especially important considering the growing demand for increasingly large forgings. Another advantage of $\mathrm{P} / \mathrm{M}$ processing is the possibility for near-net shapes. The $\mathrm{P} / \mathrm{M}$ route is being successfully applied to other similar Ni-base alloys such as Alloy 625 [7], MERL 76, René 88DT [8] and René 95 [9]. The objective of the work performed here was to investigate the effects of a thermo-mechanical Treatment (TMT) on microstructure and mechanical properties of $\mathrm{P} / \mathrm{M} 706$.

\section{Fxperimental Procedure}

P/M 706 powders were produced by both nitrogen and argon gas atomization. Nitrogen atomized 706 was screened to -60 mesh size $(250 \mu \mathrm{m})$, argon atomized 706 was screened to -140 mesh size $(106 \mu \mathrm{m})$, representing the most and least expensive versions. Both variants were hot isostatically pressed (HIP) at two different temperatures, $1950^{\circ} \mathrm{F}\left(1065^{\circ} \mathrm{C}\right)$ and $2065^{\circ} \mathrm{F}\left(1130^{\circ} \mathrm{C}\right)$ and subsequently forged to pancakes of 1.5" height and 5.5" diameter. In the following, the argon atomized material will be referred to as A706, the nitrogen atomized material as N706. N706 and A706 differ mainly in their nitrogen content. The chemical compositions of both versions are given in Table I.

Compression tests were conducted at temperatures of 1700,1800 and $1900^{\circ} \mathrm{F}\left(925,980\right.$ and $\left.1035^{\circ} \mathrm{C}\right)$ and a strain rate of $0.05 \mathrm{~s}^{-1}$. Cylindrical specimens of $1.125^{\prime \prime}(28.6 \mathrm{~mm})$ diameter and $0.75^{\prime \prime}(19.1 \mathrm{~mm})$ height were used. Blanks for microstructural investigations and mechanical testing were solutioned for 1 hour at $1800^{\circ} \mathrm{F}\left(980^{\circ} \mathrm{C}\right)$, aged for 10 hours at $1350^{\circ} \mathrm{F}\left(732^{\circ} \mathrm{C}\right)$ plus 8 hours at $1150^{\circ} \mathrm{F}\left(620^{\circ} \mathrm{C}\right)$. Samples for microscopic evaluations were mounted, ground with $\mathrm{SiC}$ paper, polished with diamond paste and electrolytically polished for $25 \mathrm{sec}$ at $30 \mathrm{~V}$ with a solution of $20 \%$ sulphuric acid in methanol [10]. They were etched with Kalling's reagent for optical microscopy (OM). For scanning electron microscopy (SEM), samples were electrolytically etched for $10 \mathrm{sec}$ at $5 \mathrm{~V}$ in a solution of $172 \mathrm{ml} \mathrm{H}_{3} \mathrm{PO}_{4}, 10 \mathrm{ml} \mathrm{H}_{2} \mathrm{SO}_{4}$ and $16 \mathrm{~g} \mathrm{CrO}_{3}$ [10]. The as-HIP materials and the forged, solutionized and aged materials were investigated by optical microscopy, SEM and EDX. Grain size was determined using AS'I'M El112. Tensile, Charpy impact and fracture toughness testing was conducted per ASTM E8, E23 and E813, respectively. LCF tests were conducted at $0.7 \%$ plastic strain using a triangular waveform with a frequency of 20 cycles per minute and an A-ratio of 1 (switched to load control at $5 \mathrm{~Hz}$ after 28,800 cycles).

Table I. Chemical Composition (wt\%)

\begin{tabular}{|c|c|c|c|c|c|c|c|c|c|c|c|c|}
\hline Heat & $\mathrm{Ni}$ & $\mathrm{Cr}$ & $\mathrm{Nb}$ & $\mathrm{Ti}$ & $\mathrm{Al}$ & $\mathrm{Si}$ & $\mathrm{P}$ & $\mathrm{S}$ & $N$ & $\mathrm{C}$ & $\mathrm{O}$ & $\mathrm{Fe}$ \\
\hline \hline A706 & 40.93 & 15.75 & 3.11 & 1.68 & 0.18 & $<0.01$ & $\leq .002$ & .001 & .001 & .004 & .0109 & 38.34 \\
\hline N706 & 40.82 & 16.01 & 3.02 & 1.65 & 0.20 & $<0.01$ & $\leq .002$ & .001 & .039 & .003 & .0072 & 38.25 \\
\hline
\end{tabular}

* Inconel ${ }^{\circledR}$ is a registered trademark of the INCO family of companies. 


\section{Results}

Following HIP, both alloys reveal a generally very fine microstructure as expected for $\mathrm{P} / \mathrm{M}$ processed materials (Figure 1). The outlines of the former powder particles can be distinguished in N706, but not in A706. HIP at $1950^{\circ} \mathrm{F}\left(1065^{\circ} \mathrm{C}\right)$ leads to somewhat finer grains than $\mathrm{HIP}$ at $2065^{\circ} \mathrm{F}\left(1130^{\circ} \mathrm{C}\right)$. Average grain sizes of the as HIP materials range from $13 \mu \mathrm{m}$ for N706, -60 mesh $(250 \mu \mathrm{m})$, HIP at $1950^{\circ} \mathrm{F}$ $\left(1065^{\circ} \mathrm{C}\right)$ to $17 \mu \mathrm{m}$ for $\mathrm{A} 706,-140 \mathrm{mesh}(106 \mu \mathrm{m}), \mathrm{HIP}$ at $2065^{\circ} \mathrm{F}\left(1130^{\circ} \mathrm{C}\right)$ (ASTM No. 9.2 to 8.4$)$ [11]. Annealing heat treatments at temperatures between 2075 and $2200^{\circ} \mathrm{F}\left(1135\right.$ and $\left.1205^{\circ} \mathrm{C}\right)$ cause only moderate grain growth to sizes around $20 \mu \mathrm{m}$ (ASTM No.8) for all conditions investigated here [11].

In the consolidated materials, discrete precipitates decorate prior powder particle surfaces (Figure 2). In N706, precipitates are also present within prior powder particles, while in A 706 there are very few of those. EDX analysis reveals that these precipitates are titanium-, niobium- and niobium-titanium compounds, presumably carbonitrides. They pin the grain boundaries during heat treatment or thermomechanical processing and restrain grain growth. N706 contains more and larger precipitates than A706 due to it's higher nitrogen content of $0.04 \%$, which accounts for the even finer grain size of the former.

The typical, but very fine pancake microstructure following the forging simulator tests is shown in Figure 3. The partly recrystallized grain structure bears no resemblance with the original as-HIP microstructure. During an annealing heat treatment, a small amount of grain growth takes place and results in an equiaxed

a)

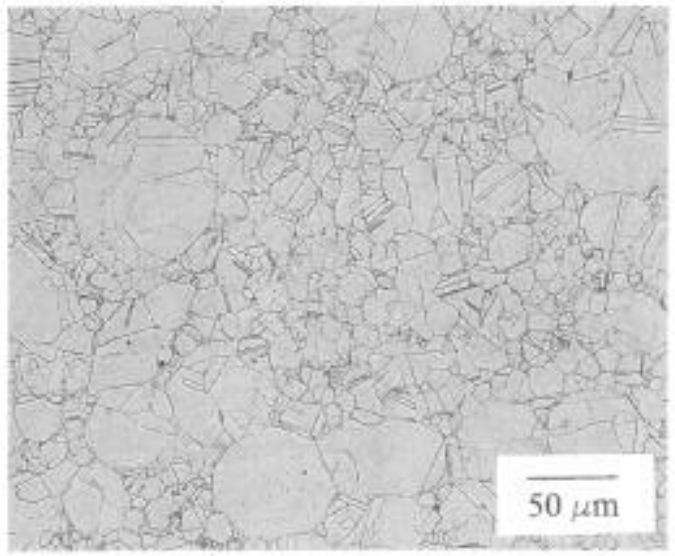

c)

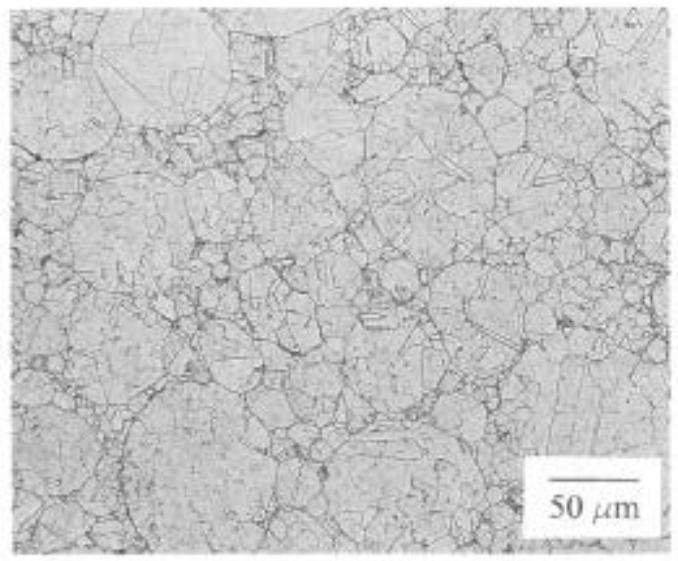

Figure 1 As-HIP microstructure of $\mathrm{P} / \mathrm{M} 706$

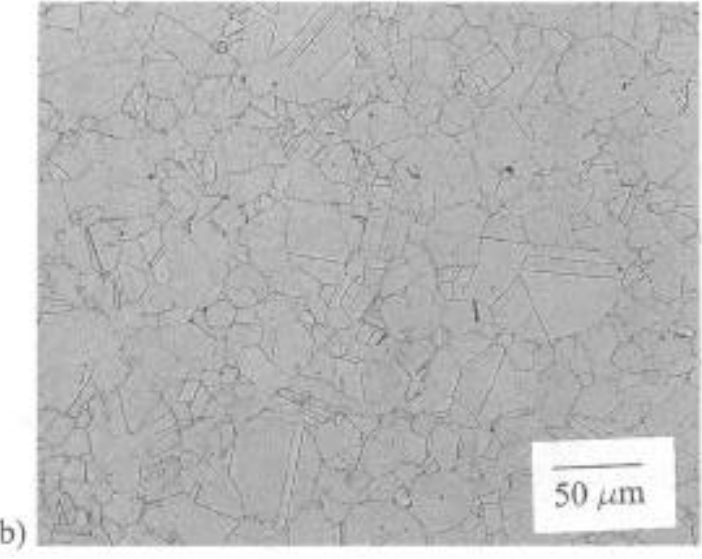

d)

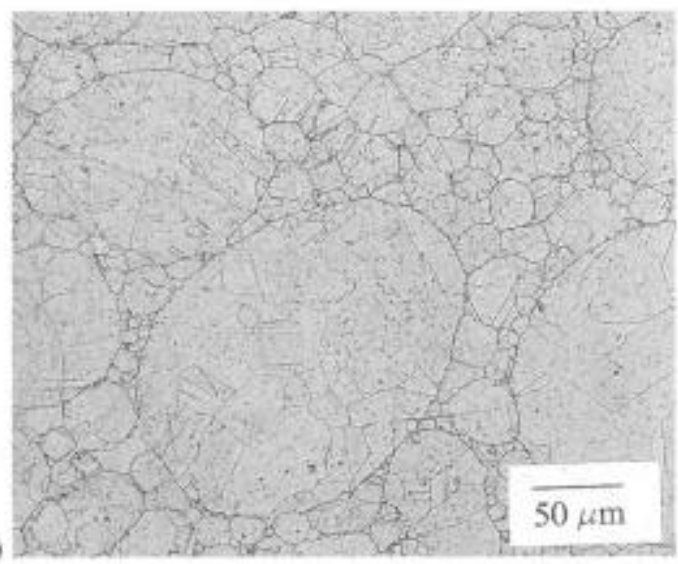

a) A706, $-140 \mathrm{mesh}(106 \mu \mathrm{m}), \mathrm{HIP}$ at $1950^{\circ} \mathrm{F}\left(1065^{\circ} \mathrm{C}\right)$

b) A706, - $140 \mathrm{mesh}(106 \mu \mathrm{m}), \mathrm{HIP}$ at $2065^{\circ} \mathrm{F}\left(1130^{\circ} \mathrm{C}\right)$

c) N706, -60 mesh $(250 \mu \mathrm{m}), \mathrm{HIP}$ at $1950^{\circ} \mathrm{F}\left(1065^{\circ} \mathrm{C}\right)$

d) N706, -60 mesh $(250 \mu \mathrm{m}), \mathrm{HIP}$ at $2065^{\circ} \mathrm{F}\left(1130^{\circ} \mathrm{C}\right)$ 
a)

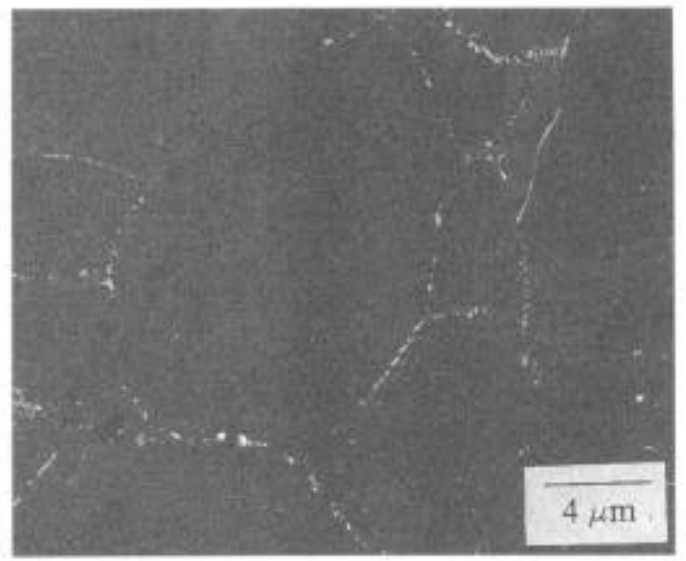

b)

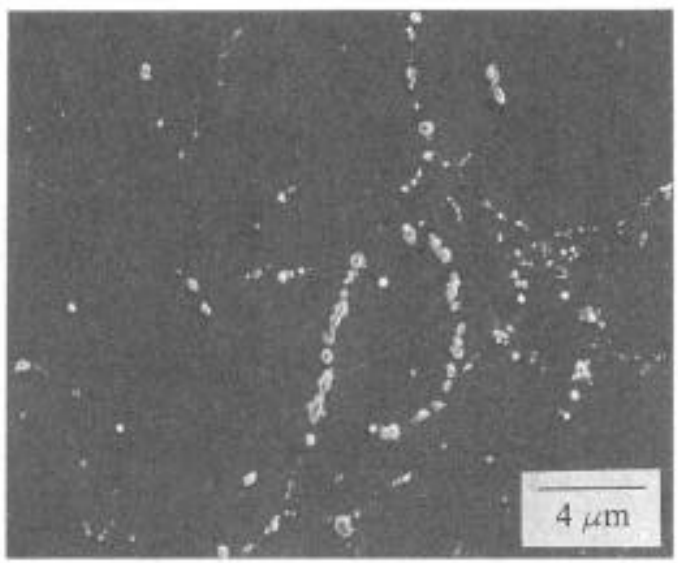

Figure 2 As-HIP microstructure of P/M 706

a) A706, -140 mesh $(250 \mu \mathrm{m}), \mathrm{HIP}$ at $2065^{\circ} \mathrm{F}\left(1130^{\circ} \mathrm{C}\right)$ (SEM)

b) N706, -60 mesh $(250 \mu \mathrm{m}), \mathrm{HIP}$ at $2065^{\circ} \mathrm{F}\left(1130^{\circ} \mathrm{C}\right)$ a)

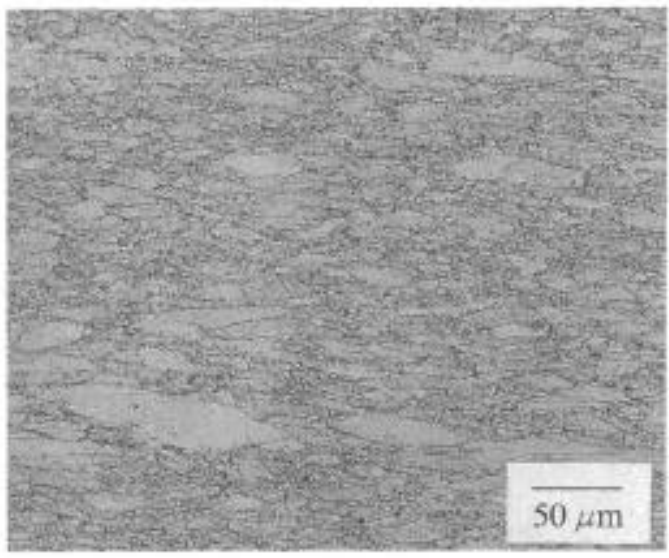

c)

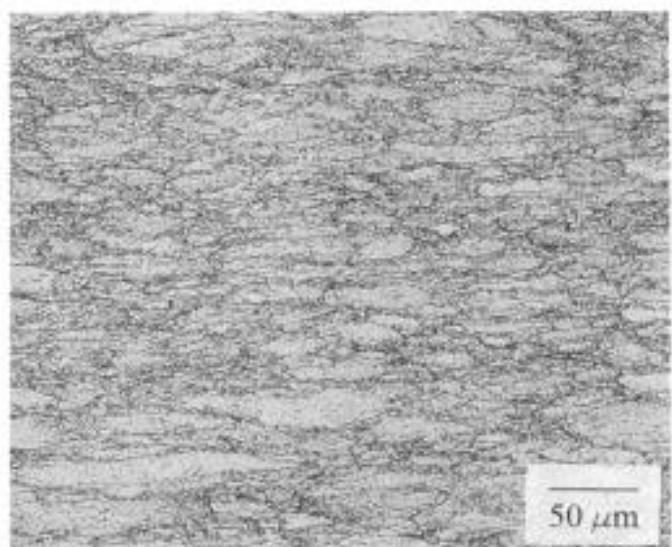

b)
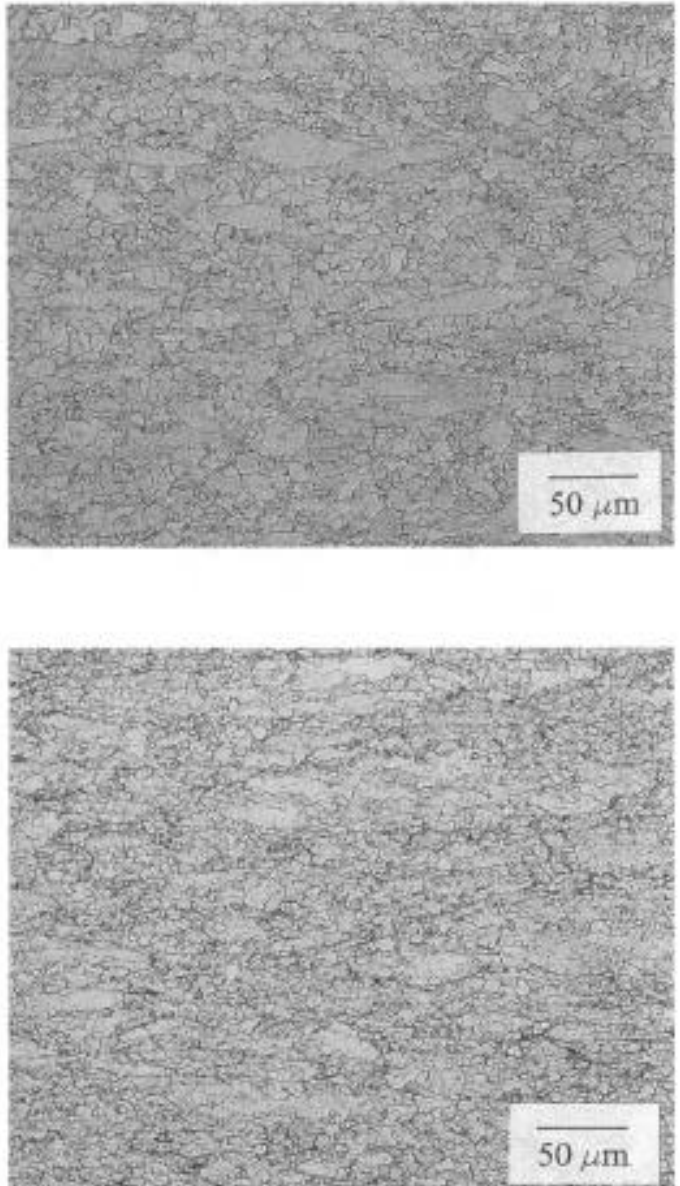

Figure 3 Microstructure of P/M 706 samples following hot compression tests

a) A706, -140 mesh $(106 \mu \mathrm{m})$, HIP at $2065^{\circ} \mathrm{F}\left(1130^{\circ} \mathrm{C}\right)$, deformed at $1700^{\circ} \mathrm{F}\left(925^{\circ} \mathrm{C}\right)$

b) $\mathrm{A} 706,-140 \mathrm{mesh}(106 \mu \mathrm{m}), \mathrm{HIP}$ at $2065^{\circ} \mathrm{F}\left(1130^{\circ} \mathrm{C}\right)$, deformed at $1900^{\circ} \mathrm{F}\left(1035^{\circ} \mathrm{C}\right)$

c) N706, -60 mesh $(250 \mu \mathrm{m})$, HIP at $2065^{\circ} \mathrm{F}\left(1130^{\circ} \mathrm{C}\right)$, deformed at $1700^{\circ} \mathrm{F}\left(925^{\circ} \mathrm{C}\right)$

d) N706, -60 mesh $(250 \mu \mathrm{m}), \mathrm{HIP}$ at $2065^{\circ} \mathrm{F}\left(1130^{\circ} \mathrm{C}\right)$, deformed at $1900^{\circ} \mathrm{F}\left(1035^{\circ} \mathrm{C}\right)$ 
grain shape (Figure 4). The quantitative analysis is given in Table II. The average grain size after hot compression tests is $5 \mu \mathrm{m}$ for N706, -60 mesh $(250 \mu \mathrm{m})$, HIP at $2065^{\circ} \mathrm{F}\left(1130^{\circ} \mathrm{C}\right)$, deformed at $1700^{\circ} \mathrm{F}$ $\left(925^{\circ} \mathrm{C}\right)$ to $8 \mu \mathrm{m}$ for $\mathrm{A} 706,-140 \mathrm{mesh}(106 \mu \mathrm{m}), \mathrm{HIP}$ at $2065^{\circ} \mathrm{F}\left(1130^{\circ} \mathrm{C}\right)$, deformed at $1900^{\circ} \mathrm{F}\left(1035^{\circ} \mathrm{C}\right)$ which corresponds to ASTM No. 11 to 12 , respectively. Following additional 4 hours at $2000^{\circ} \mathrm{F}\left(1095^{\circ} \mathrm{C}\right)$, the grain size increases from $13 \mu \mathrm{m}$ to $22 \mu \mathrm{m}$ (ASTM No. 7.5 to 9.5).

Table II Grain Size of P/M $706(\mu \mathrm{m})$ as-deformed and heat treated. All materials HIP at $2065^{\circ} \mathrm{F}$.

\begin{tabular}{||c|c|c||c|c|c||}
\hline \hline Grade & $\begin{array}{c}\text { Mesh } \\
\text { size }\end{array}$ & $\begin{array}{c}\text { Deformation Temp. } \\
\left({ }^{\circ} \mathrm{F}\left({ }^{\circ} \mathrm{C}\right)\right)\end{array}$ & As-Deformed & $\begin{array}{c}\text { Deformed }+ \\
8 \mathrm{hrs} \mathrm{1800}{ }^{\circ} \mathrm{F}\end{array}$ & $\begin{array}{c}\text { Deformed }+ \\
4 \mathrm{hrs} \mathrm{2000}{ }^{\circ} \mathrm{F}\end{array}$ \\
\hline \hline N706 & -60 & $1700(925)$ & $5.4+/-0.5$ & $13.5+/-1$ & $20+/-0.5$ \\
\hline N706 & -60 & $1800(980)$ & $5.8+/-0.9$ & $11.5+/-1$ & $17+/-4$ \\
\hline N706 & -60 & $1900(1035)$ & $8.0+/-0.7$ & $12+/-1$ & $13+/-0.5$ \\
\hline A706 & -140 & $1700(925)$ & $7.6+/-1.0$ & $15.5+/-1$ & $18+/-0.6$ \\
\hline A706 & -140 & $1800(980)$ & $6.6+/-0.4$ & $13.5+/-1$ & $22+/-1$ \\
\hline A706 & -140 & $1900(1035)$ & $7.0+/-0.7$ & $15+/-1$ & $20+/-2$ \\
\hline
\end{tabular}

Room temperature mechanical properties of HIP, solutionized and aged P/M 706 are shown in Table III. Despite their differences in processing, all conditions exhibit very similar tensile strength and tensile ductility. All conditions exhibit a $0.2 \%$ yield strength around $150 \mathrm{ksi}(1035 \mathrm{MPa})$, while their UTS is around $192 \mathrm{ksi}(1325 \mathrm{MPa})$. The tensile elongations are around $21 \%$; the reductions of area are around $28 \%$. Charpy impact strength is $26 \mathrm{ft}-\mathrm{lb}$ ( $35 \mathrm{~J})$ for N706, but with about $20 \mathrm{ft}-\mathrm{lb}(27 \mathrm{~J})$ lower for the other three conditions. Fractography reveals a general absence of ball-and-sucket fracture, indicating that the prior powder particles are not a weak path of least resistance to fracture. This is also evident in the good ductility observed [11].

The high temperature flow stress curves obtained from the isothermal compression tests show that the flow stress of the P/M 706 decreases significantly with increasing temperatures, from $38 \mathrm{ksi}$ ( $246 \mathrm{MPa}$ ) to 22.3 $\mathrm{ksi}(154 \mathrm{MPa})$ as the temperature is raised from $1700 \mathrm{~F}$ to $1900 \mathrm{~F}$ [12]. When compared to $\mathrm{C} / \mathrm{W} 706$ material for the same test conditions, the $\mathrm{P} / \mathrm{M}$ matcrials show an $8-22 \%$ lowcr flow strcss depending upon temperature and strain rate (either .05 or. $5 / \mathrm{sec}$ ) [12]. In general, the P/M material exhibits less strain rate sensitivity over the range of strain rates tested. There did not appear to be any difference in the flow stress behavior for the P/M materials as atomization gas, mesh size or HIP temperature were changed.

The mlechanical properties of HIP, forged, solution treated and aged P/M 706 are given in Tables IV and V. Again, all conditions exhibit very similar tensile strength and tensile ductility. Charpy impact and fracture toughness of N706 are higher than of A706, while low cycle fatigue lifetimes of A706 are better than of N706. Reduction of area ( 39 to $44 \%$ ) and Charpy impact toughness ( 28 to $37 \mathrm{ft}-1 \mathrm{bs}$ ( 38 to $50 \mathrm{~J}$ ))

Table III Room temperature mechanical properties of P/M 706, HIP, solution treated and aged.

\begin{tabular}{||c|c|c||c|c|c|c|c||}
\hline \hline Grade & $\begin{array}{c}\text { Mesh } \\
\text { size }\end{array}$ & $\begin{array}{c}\text { HIP Temp. } \\
\left({ }^{\circ} \mathrm{F}\left({ }^{\circ} \mathrm{C}\right)\right)\end{array}$ & $\begin{array}{c}0.2 \% \text { YS } \\
(\mathrm{ksi}(\mathrm{MPa}))\end{array}$ & $\begin{array}{c}\text { UTS } \\
(\mathrm{ksi}(\mathrm{MPa}))\end{array}$ & $\begin{array}{c}\text { Tens. El. } \\
(\%)\end{array}$ & $\begin{array}{c}\text { RA } \\
(\%)\end{array}$ & $\begin{array}{c}\text { Impact Energy } \\
(\mathrm{ft}-1 \mathrm{~b}(\mathrm{~J}))\end{array}$ \\
\hline \hline N706 & -60 & $2065(1130)$ & $149(1025)$ & $192(1325)$ & 23 & 30 & $26(35)$ \\
\hline N706 & -60 & $1950(1065)$ & $150(1035)$ & $192(1325)$ & 19 & 25 & $20(27)$ \\
\hline A706 & -140 & $2065(1130)$ & $150(1035)$ & $193(1330)$ & 20 & 27 & $19(26)$ \\
\hline A706 & -140 & $1950(1065)$ & $151(1040)$ & $195(1345)$ & 21 & 29 & $20(27)$ \\
\hline
\end{tabular}


are significantly improved compared to the HIP, solution treated and aged material. However, the strength levels, especially the yield strength (123 to $125 \mathrm{ksi}(845$ to $861 \mathrm{MPa})$ ) are lower than in the HIP, solution treated and aged condition. The fracture toughness ranges from 420 to $533 \mathrm{in}-\mathrm{lbs} / \mathrm{in}^{2}\left(7.4\right.$ to $9.3 \cdot 10^{-2}$ $\left.\mathrm{Nm} / \mathrm{m}^{2}\right)$. Low cycle fatigue lifetimes are above 26,00 cycles at $1380^{\circ} \mathrm{F}\left(750^{\circ} \mathrm{C}\right)$ and above 32,000 at $1650^{\circ} \mathrm{F}\left(900^{\circ} \mathrm{C}\right)$.

Table IV Room temperature mechanical properties of P/M 706, HIP, forged, solution treated and aged.

\begin{tabular}{||c|c|c||c|c|c|c|c||}
\hline \hline Alloy & $\begin{array}{c}\text { Mesh } \\
\text { size }\end{array}$ & $\begin{array}{c}\text { HIP Temp. } \\
\left({ }^{\circ} \mathrm{F}\left({ }^{\circ} \mathrm{C}\right)\right)\end{array}$ & $\begin{array}{c}0.2 \% \text { YS } \\
(\mathrm{ksi}(\mathrm{MPa}))\end{array}$ & $\begin{array}{c}\text { UTS } \\
(\mathrm{ksi}(\mathrm{MPa}))\end{array}$ & $\begin{array}{c}\text { Tens. El. } \\
(\%)\end{array}$ & $\begin{array}{c}\text { RA } \\
(\%)\end{array}$ & $\begin{array}{c}\text { Impact Energy } \\
(\mathrm{ft}-\mathrm{lb}(\mathrm{J}))\end{array}$ \\
\hline \hline N706 & -60 & $2065(1130)$ & $125(860)$ & $177(1205)$ & 23 & 44 & $37(50)$ \\
\hline N706 & -60 & $1950(1065)$ & $125(855)$ & $177(1206)$ & 23 & 44 & $36(49)$ \\
\hline A706 & -140 & $2065(1130)$ & $124(855)$ & $177(1205)$ & 22 & 40 & $30(41)$ \\
\hline A706 & -140 & $1950(1065)$ & $123(845)$ & $175(1190)$ & 23 & 39 & $28(38)$ \\
\hline
\end{tabular}

a)

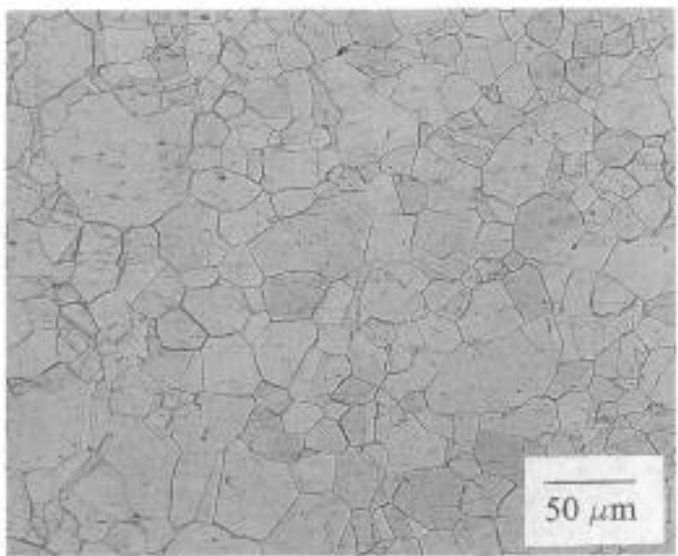

c)

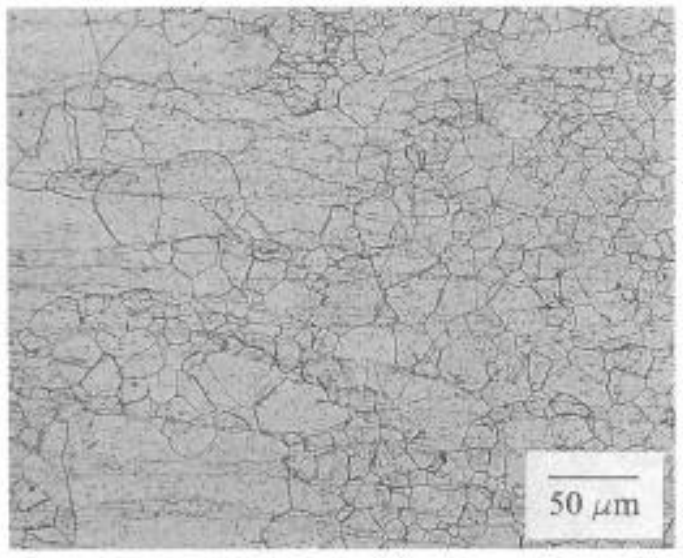

b)

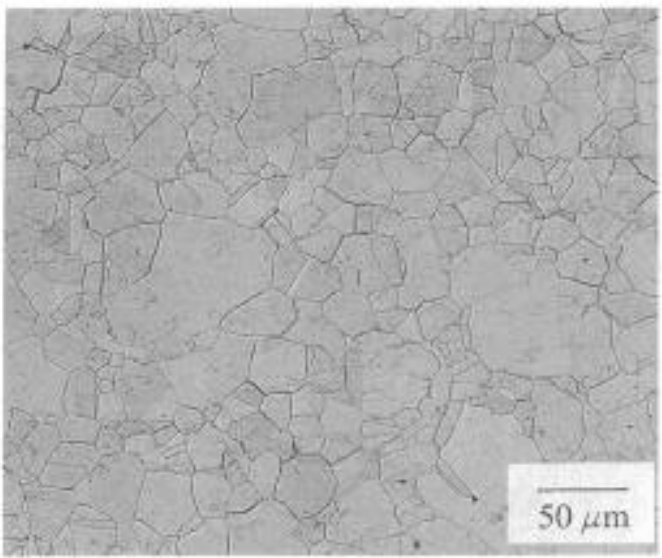

d)

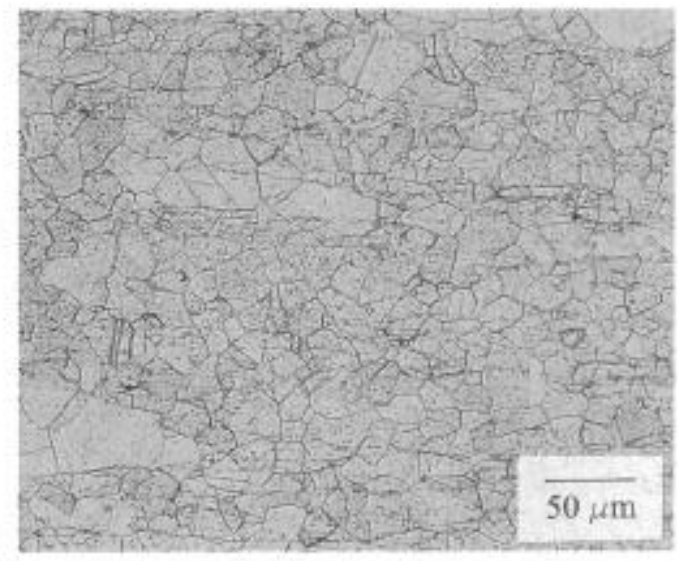

Figure 4 Microstructure of compressed P/M 706 samples annealed 4 hrs at $2000^{\circ} \mathrm{F}\left(1095^{\circ} \mathrm{C}\right)$ a) A706, -140 mesh $(106 \mu \mathrm{m}), \mathrm{HIP}$ at $2065^{\circ} \mathrm{F}\left(1130^{\circ} \mathrm{C}\right)$, deformed at $1700^{\circ} \mathrm{F}\left(925^{\circ} \mathrm{C}\right)$ b) A706, -140 mesh $(106 \mu \mathrm{m})$, HIP at $2065^{\circ} \mathrm{F}\left(1130^{\circ} \mathrm{C}\right)$, deformed at $1900^{\circ} \mathrm{F}\left(1035^{\circ} \mathrm{C}\right)$ c) N706, -60 mesh $(250 \mu \mathrm{m}), \mathrm{HIP}$ at $2065^{\circ} \mathrm{F}\left(1130^{\circ} \mathrm{C}\right)$, deformed at $1700^{\circ} \mathrm{F}\left(925^{\circ} \mathrm{C}\right)$ d) N706, -60 mesh $(250 \mu \mathrm{m}), \mathrm{HIP}$ at $2065^{\circ} \mathrm{F}\left(1130^{\circ} \mathrm{C}\right)$, deformed at $1900^{\circ} \mathrm{F}\left(1035^{\circ} \mathrm{C}\right)$ 
Table V Room temperature fracture toughness and cycles to failure (LCF) at $0.7 \%$ strain at 1380 and $1650^{\circ} \mathrm{F}\left(750\right.$ and $\left.900^{\circ} \mathrm{C}\right)$ of $\mathrm{P} / \mathrm{M} 706, \mathrm{HIP}$, forged, solution treated and aged.

\begin{tabular}{||c|c|c||c|c|c|c||}
\hline \hline Alloy & Mesh size & $\begin{array}{c}\text { HIP Temp. } \\
\left({ }^{\circ} \mathrm{F}\left({ }^{\circ} \mathrm{C}\right)\right)\end{array}$ & $\begin{array}{c}\mathrm{J}_{\mathrm{IC}} \\
\left(\mathrm{in} \cdot \mathrm{lbs} / \mathrm{in}^{2}\right. \\
\left.\left(10^{-2} \cdot \mathrm{Nm} / \mathrm{m}^{2}\right)\right)\end{array}$ & $\begin{array}{c}\mathrm{K}_{\mathrm{I}} \\
\left(\mathrm{ksi} \cdot \mathrm{in}^{1 / 2}\right. \\
\left.\left(\mathrm{MPa} \cdot \mathrm{m}^{1 / 2}\right)\right)\end{array}$ & $\begin{array}{c}\text { Cycles to } \\
\text { failure at } \\
750^{\circ} \mathrm{C}\end{array}$ & $\begin{array}{c}\text { Cycles to } \\
\text { failure at } \\
900^{\circ} \mathrm{C}\end{array}$ \\
\hline \hline N706 & -60 & $2065(1130)$ & - & - & 34,312 & 32,820 \\
\hline N706 & -60 & $1950(1065)$ & $533(9.3)$ & $133(145)$ & 26,515 & 52,423 \\
\hline A706 & -140 & $2065(1130)$ & $426(7.5)$ & $119(130)$ & 41,846 & 64,055 \\
\hline A706 & -140 & $1950(1065)$ & $420(7.4)$ & $118(129)$ & 27,623 & 45,916 \\
\hline
\end{tabular}

\section{Discussion}

$\mathrm{P} / \mathrm{M} 706$ processed as described herein is fully dense and has a very fine microstructure. The rapid cooling rate inherent to $\mathrm{P} / \mathrm{M}$ processing results in very fine cellular solidification microstructures in the as-atomized powders, while segregation is largely absent [12]. Also, the inclusion size is limited by the mesh size during powder screening. The very small grain size observed here is due to grain boundary pinning during thermo-mechanical processing by the finely dispersed carbonitride precipitates. Similar effects have been observed in nitrogen atomized Alloy 625 [13]. This is most pronounced for nitrogen atomized P/M 706 with the larger number of carbonitrides. Annealing studies of hot forged P/M 706 indicate higher resistance to grain growth in this material as compared to $\mathrm{C} / \mathrm{W} 706$ [6]: P/M 706 has five to eight times maller grains than C/W 706 [6] after the same high temperature exposure (Figure 5). This corresponds to ASTM No. 8 for P/M material vs. No. 2 for C/W material or No. 9 for P/M material vs. No. 5 for C/W material [6]. The significantly reduced propensity for grain growth may allow higher forging temperatures during processing and therefore require lower forging forces. Also, the finer grain size leads to improved ultrasonic inspectability due to a reduced noise level. A decrease in grain size from ASTM No. 3 to ASTM No. 8 has been found to decrease the ultrasonic noise level by factors of 3 to 5 times [14]

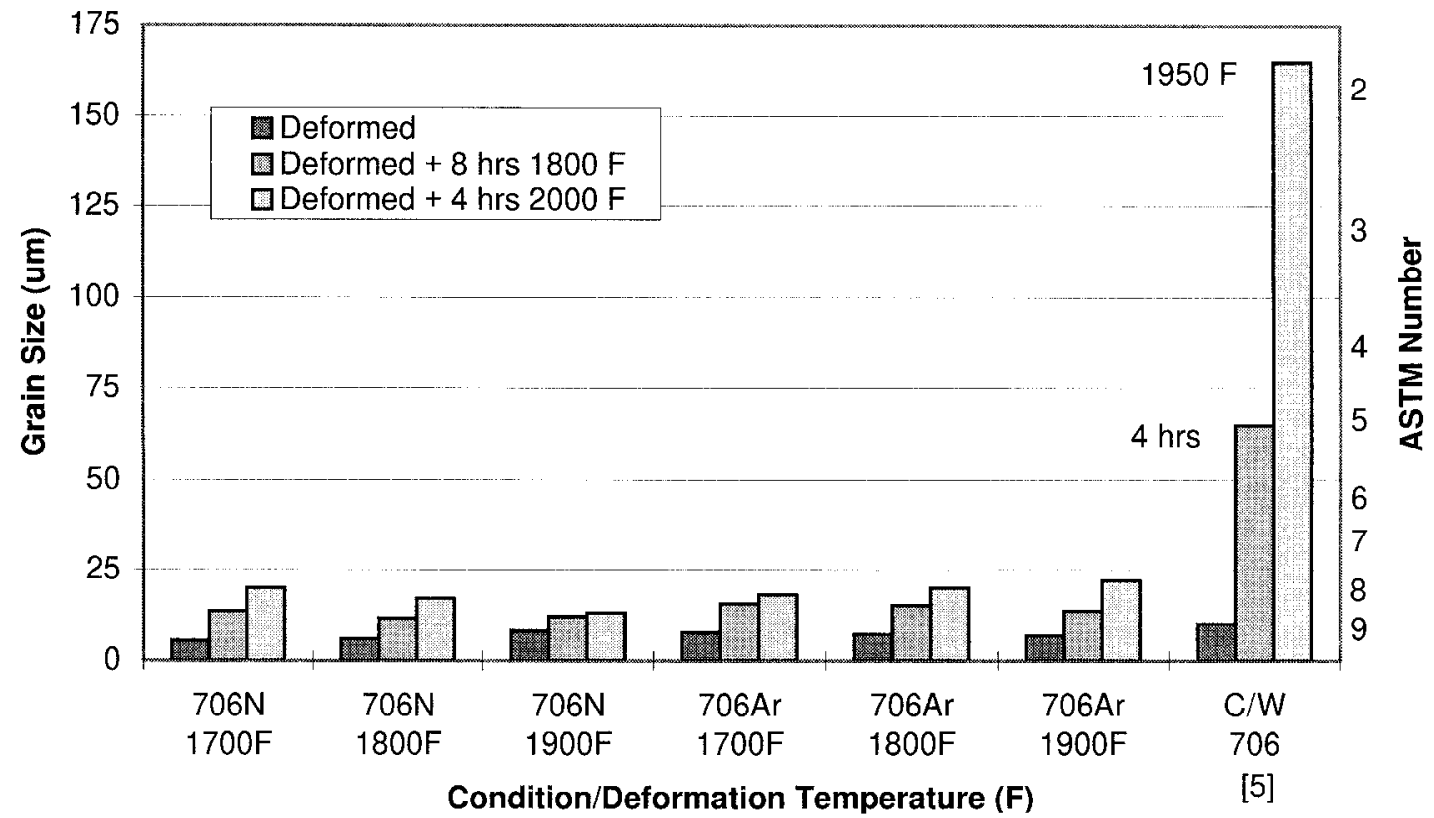

Figure 5 Grain size of deformed P/M 706 and C/W 706 after heat treating 
Precipitates and other phases observed in aged P/M 706 are similar to the ones observed in C/W 706 with corresponding thermo-mechanical treatment. Alloy 706 is precipitation strengthened by $\gamma^{\prime}-, \gamma^{\prime \prime}$ - and $\gamma^{\prime} / \gamma^{\prime \prime}$ compound-phases and $\delta, \eta$ - and Laves-phases can precipitate also [2]. Large amounts of grain boundary $\delta, \eta$ - and Laves-phase degrade ductility and impact properties [2]. Properly distributed, the same phases pin grain boundaries during thermo-mechanical treatments resulting in finer grain sizes [2,3]. In the HIP $\mathrm{P} / \mathrm{M} 706$, fine intragranular precipitates of $\gamma^{\prime}$ - and $\gamma^{\prime \prime}$-phase and larger intergranular precipitates are present as expected following heat treatment (Figure 6a, c). Their size is comparable to those observed peak-aged C/W 706 [3]. Also, $\eta$ - and Laves-phases appear preferentially on grain boundaries. In the HIP plus forged material, the same phases are present, but they are much coarser (Figure 6b, d). These observations reveal that the same standard heat treatment introduces a peak-aged microstructure in the HIP P/M 706 and a severely overaged microstructure in the HIP plus forged P/M 706. This is presumably due to the faster kinetics in $\mathrm{P} / \mathrm{M} 706$ compared to $\mathrm{C} / \mathrm{W} 706$ or HIP P/M 706. Differences in ageing kinetics between $\mathrm{P} / \mathrm{M}$ and $\mathrm{C} / \mathrm{W}$ versions of the same alloy have been observed in the past [15].

No significant differences in strength have been observed between the HIP, solution heat treated and aged versions of $\mathrm{P} / \mathrm{M} 706$ despite some difference in grain sizes. Similarly, the HIP, forged, solution heat treated and aged versions of $\mathrm{P} / \mathrm{M} 706$ show some difference in grain sizes, but not in strength. Assuming a Hall-

a)

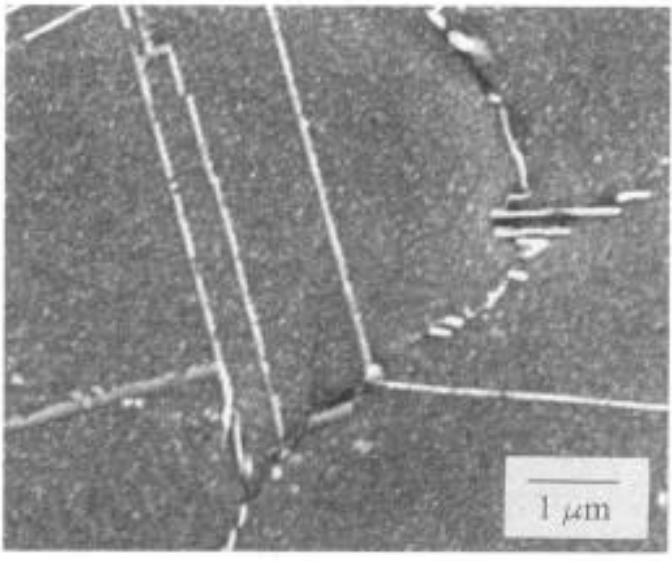

c)

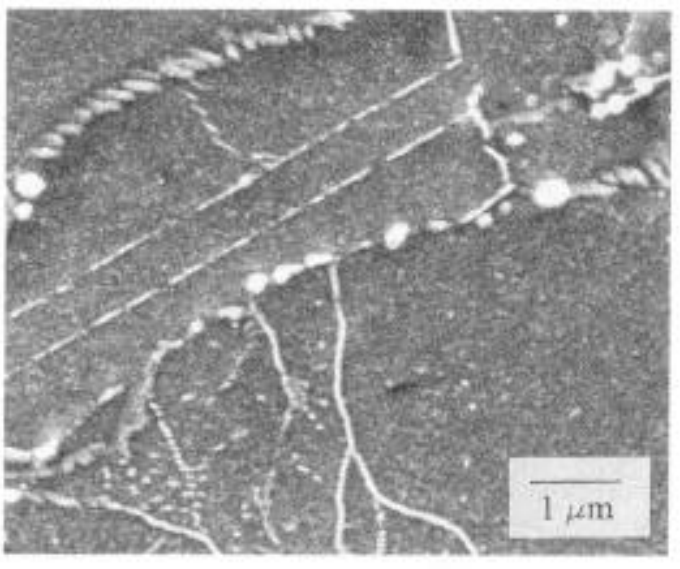

b)

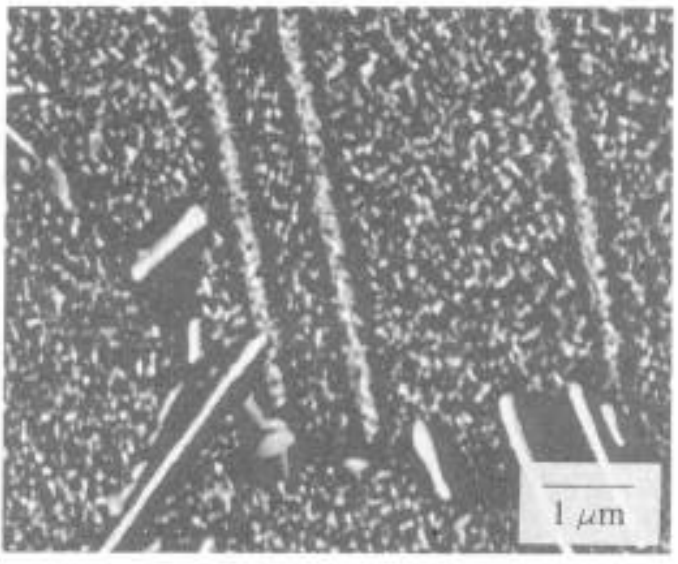

d)

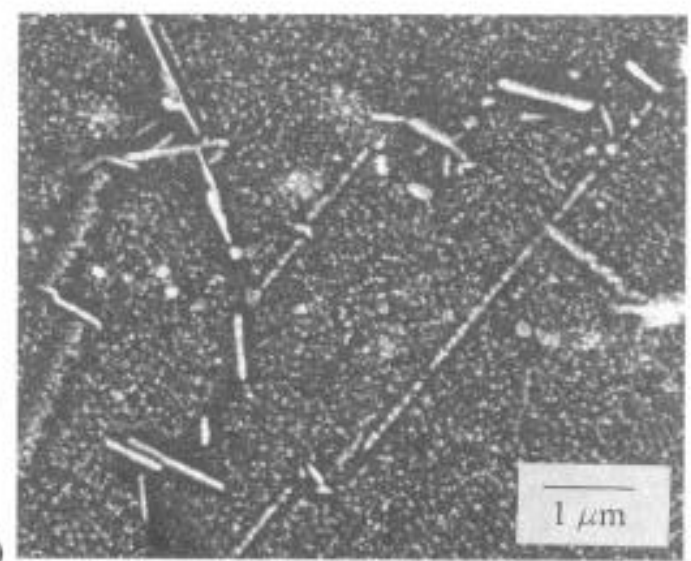

Figure 6 Microstructure of solutionized and aged P/M 706

a) A706, -140 mesh $(106 \mu \mathrm{m}), \mathrm{HIP}$ at $2065^{\circ} \mathrm{F}\left(1130^{\circ} \mathrm{C}\right)$, solution treated and aged

b) A706, -140 mesh $(106 \mu \mathrm{m})$, HIP at $2065^{\circ} \mathrm{F}\left(1130^{\circ} \mathrm{C}\right)$, forged, solution treated and aged

c) $\mathrm{N} 706,-60$ mesh $(250 \mu \mathrm{m}), \mathrm{HIP}$ at $2065^{\circ} \mathrm{F}\left(1130^{\circ} \mathrm{C}\right)$, solution treated and aged

d) $\mathrm{N} 706,-60 \mathrm{mesh}(250 \mu \mathrm{m}), \mathrm{HIP}$ at $2065^{\circ} \mathrm{F}\left(1130^{\circ} \mathrm{C}\right)$, forged, solution treated and aged 
Petch relationship for grain boundary strengthening, one would expect the contribution of this component of the strength to increase $14 \%$ from the smallest to the largest grain size in the HIP, solution heat treated and aged materials and $8 \%$ in the HIP, forged, solution heat treated and aged materials. The fact that this does not significantly change the total yield strength observed in the tensile test implies that grain boundary strengthening plays a minor role compared to precipitate strengthening. The fine grain size is expected to improve fatigue properties.

Overall, the results of room temperature mechanical testing indicate that the lowest cost powder, coarse nitrogen atomized -60 mesh $(250 \mu \mathrm{m})$, is as good as the highest cost powder, fine argon atomized -140 mesh $(106 \mu \mathrm{m})$. In the as-HIP, solution treated and aged condition, tensile properties of P/M 706 compare favorably to forged, solutionized and aged C/W 706, whilc Charpy impact strength is lower [3].

In contrast, HIP, forged, solution treated and aged P/M 706 has a lower strength than usually observed in forged, solution treated and aged C/W 706 [3]. The ductility of HIP, solution treated and aged P/M 706 exceeds $\mathrm{C} / \mathrm{W} 706$ properties [3]. The reason for the lower strength is that the standard heat treatment leads to microstructural differences between HIP P/M 706 and HIP and forged P/M 706. The above described overaged microstructure of the HIP plus forged material explains the low room temperature yield strength observed in the heat treated condition. Heat treatment and microstructurc have to be optimized to give balanced mechanical properties.

Low cycle fatigue (LCH) of HIP plus forged P/M 706 results are excellent (Table V) and exceed those of $\mathrm{C} / \mathrm{W} 706$ by factors of 3 to 5 [3]. The good low cycle fatigue resistance results in part from the very fine microstructure. Partly it might be due to the presence of large precipitates in the overaged material. The fracture toughness meets $706 \mathrm{C} / \mathrm{W}$ performance [3].

\section{Summary and Conclusions}

- Two P/M versions of the Superalloy 706 have been produced by argon and nitrogen atomization. Both have a very fine and homogeneous microstructure with grain sizes of ASTM No. 7 to 11.5 depending on thermo-mechanical treatment.

- P/M 706 in general has a significantly lower propensity for grain growth than C/W 706. Higher forging temperatures with corresponding lower forging forces might be used with P/M 706 due to the resistance against grain growth of the latter.

- Precipitates and other phases observed in aged P/M 706 are comparable to C/W 706 with similar thermo-mechanical treatment, but the ageing kinetics of HIP plus forged P/M 706 are considerably faster than for HIP P/M 706.

- The compacted P/M 706 contains discrete titanium-, niobium- and titanium-niobium-carbonitride compounds which pin grain boundaries during thermo-mechanical treatment. Nitrogen-atomized P/M 706 contains more frequent and larger precipitates that argon-atomized P/M 706 and therefore has a finer grain size.

- The strength and ductility of HIP, solution treated and aged P/M 706 compare favorably to forged, solution treated and aged $\mathrm{C} / \mathrm{W} 706$.

- The lower strength of HIP, forged, solution treated and aged P/M 706 versus HIP, solution treated and aged P/M 706 and forged, solution treated and aged C/W 706 is due to overaging. The heat treatment of HIP plus forged P/M 706 has to be optimized to account for the faster aging kinetics to achieve balanced mechanical properties.

\section{Acknowledgments}

The authors thank Dr. J.F. Radavich (Micro-Met Laboratories) for advice on metallographic preparation. The assistance of T. Slater, J.F. Verduci and R.J. Hoffman (all Crucible Research) is gratefully acknowledged. 


\section{Disclaimer}

The material contained herein is intended for general information only and should not be used in relation to any specific application without independent study and determination of its applicability and suitability for the intended application. In some cases, a complete evaluation of performance is not possible without more extended tests over longer time periods. Anyone making use of this material or relying thereon assumes all risk and liability arising therefrom.

\section{References}

[1] H.L Eiselstein: "Properties of a Fabricable, High Strength Superalloy", Metals Eng. Quarterly (1971) 20

[2] C.S. Sims, N.C. Stoloff and W.C. Hagel, Superalloys II, John Wiley and Sons, New York, 1987, 167

[3] G.W. Kuhlman, A.K. Chakrabarti, R.A. Beaumont, E.D. Seaton and J.F. Radavich, "Microstructure Mechanical Properties Relationships in Inconel 706 Superalloy" in: Proc. of the International Symposium on Superalloys 718, 625, 706 and Various Derivatives, ed: E.A. Loria (Warrendale, PA: TMS, 1994), 441

[4] T. Honjo, O. Matsumoto, K. Morita, K. Hirose and M. Okamura, "Manufacturing and Mechanical Properties of a Large Size Alloy 706 Disk by ESR Process" in: Proc. of the International Symposium on Superalloys 718, 625, 706 and Various Derivatives, ed: E.A. Loria (Warrendale, PA: TMS, 1994), 239

[5] A.D. Helms, C.B. Adasczik and L.A. Jackman: "Extending the Size Limits of Cast/Wrought Superalloys", in Proc. of Superalloys 1996, eds: R.D. Kissinger, D.J. Deye, D.L. Anton, A.D. Cetel, M.V. Nathal, T.M. Pollock and D.A. Woodford (Warrendale, PA: TMS, 1996), 427

[6] P.W. Schilke, J.J. Pepe and R.C. Schwant: "Nlloy 706 Metallurgy and Turbine Whecl Application" in: Proc. of the International Symposium on Superalloys $718,625,706$ and Various Derivatives, ed: E.A. Loria (Warrendale, PA: TMS, 1994), 1

[7] F.J. Rizzo: "Nitrogen-Atomized, Nickel-Based, Corrosion-Resistant Alloys”, JOM (1996) 24

[8] C.P. Blankenship Jr., M.F. Henry, J.M.Hyzak, R.B. Rohling and E.L. Hall: "Hot-Die Forging of P/M Ni-base Superalloys", in Proc. of Superalloys 1996, eds: R.D. Kissinger, D.J. Deye, D.L. Anton, A.D. Cetel, M.V. Nathal, T.M. Pollock and D.A. Woodford (Warrendale, PA: TMS, 1996), 653

[9] J. J. Conway and J. H. Moll, "Current Status of Powder Metallurgy Near Net Shapes by Hot Isostatic Pressing", Proceedings of Third International Conference on Near Net Shape Manufacturing, Pittsburgh, PA, 27-29 September 1993, (Materials Park, OH: ASM International) pp.125-131

[10] J.F. Radavich, "Metallography of Alloy 718" JOM (1988) 42

[11] U. Habel, J.H. Moll, F.J. Rizzo and J.J. Conway: "Microstructure and Properties of HIPed P/M 706" Proc. Of the Fifth International Conference on Advanced Particulate Materials and Processes, to be published

[12] R. Pishko and V.M. Sample, unpublished results

[13] F.J. Rizzo, J.J. Conway, J.F. Radavich and J.A. Jones: "Investigation of Nitrogen Atomized Alloy $625^{\prime \prime}$ in: Proc. of the International Symposium on Superalloys 718, 625.706 and Various Derivatives, ed: E.A. Loria (Warrendale, PA: TMS, 1994), 923

[14] G.W. Kuhlman, unpublished results

[15] F.J. Rizzo and J.F. Radavich: "Microstructural Characterization of P/M 625 Type Materials" in: Proc. of the International Symposium on Superalloys $718,625,706$ and Various Derivatives, ed: E.A. Loria (Warrendale, PA: TMS, 1991), 297 